Original Research

Agrinula : Jurnal Agroteknologi dan Perkebunan 2020 vol. 3 (2): 73-83

website : https://journal.utnd.ac.id/index.php/agri

E-ISSN : 2655-7673

DOI : https://doi.org/10.36490/agri.v3i2.102

REGRESI FAKTOR CURAH HUJAN, KELEMBABAN UDARA, DAN HARI HUJAN TERHADAP PRODUKSI LADA SERTA ALTERNATIF KEBIJAKAN DI SUMATERA UTARA

\title{
REGRESSION FACTORS OF RAINFALL, HUMIDITY, AND RAINY DAY ON PEPPER YIELD AND POLICY ALTERNATIVES IN NORTH SUMATRA
}

\section{Fransisca Natalia Sihombing ${ }^{1}$, Koko Tampubolon $^{2 *}$, \& Triara Juniarsih ${ }^{2}$}

${ }^{1}$ Program Magister Agribisnis, Fakultas Pertanian, Universitas Sumatera Utara, Medan 20155, Sumatera Utara, Indonesia.

${ }^{2}$ Program Studi Agroteknologi, Fakultas Pertanian dan Peternakan, Universitas Tjut Nyak Dhien, Medan 20123, Sumatera Utara, Indonesia.

*Koresponding author: koko.tampubolon@gmail.com

\begin{tabular}{|c|c|}
\hline Informasi Artikel & ABSTRAK \\
\hline $\begin{array}{l}\text { Disubmit: } \\
06 \text { Oktober } 2020 \\
\text { Direvisi: } \\
\text { 10 Oktober } 2020 \\
\text { Diterima: } \\
12 \text { Oktober } 2020 \\
\text { Dipublikasi : } \\
\text { 14 Oktober } 2020\end{array}$ & $\begin{array}{l}\text { Pendahuluan: Penelitian ini bertujuan untuk } \\
\text { mendapatkan pola hubungan curah hujan, kelembaban } \\
\text { udara, dan hari hujan terhadap peningkatan produksi lada } \\
\text { di Sumatera Utara. } \\
\text { Metode Penelitian: Penelitian ini menggunakan data } \\
\text { time-series faktor curah hujan, kelembaban udara, hari } \\
\text { hujan dan produksi lada selama } 14 \text { tahun }(2005-2018) \text {. } \\
\text { Analisis data menggunakan analisis regresi linier } \\
\text { berganda menggunakan software EViews } 10 \text {. } \\
\text { Hasil Penelitian: Curah hujan, kelembaban udara, dan } \\
\text { hari hujan secara keseluruhan signifikan meningkatkan } \\
\text { produksi tanaman lada sebesar 55,767\% di Sumatera } \\
\text { Utara. Setiap peningkatan } 1 \% \text { kelembaban udara dapat } \\
\text { meningkatkan produksi tanaman lada sebesar } 0,455 \text { ton, } \\
\text { namun peningkatan } 1 \text { mm/tahun curah hujan dan } 1 \text { hari } \\
\text { hujan dapat menurunkan produksi lada di Sumatera } \\
\text { Utara masing-masing sebesar } 0,503 \text { dan } 1,866 \text { ton. } \\
\text { Kelembaban udara bernilai positif sedangkan curah }\end{array}$ \\
\hline
\end{tabular}




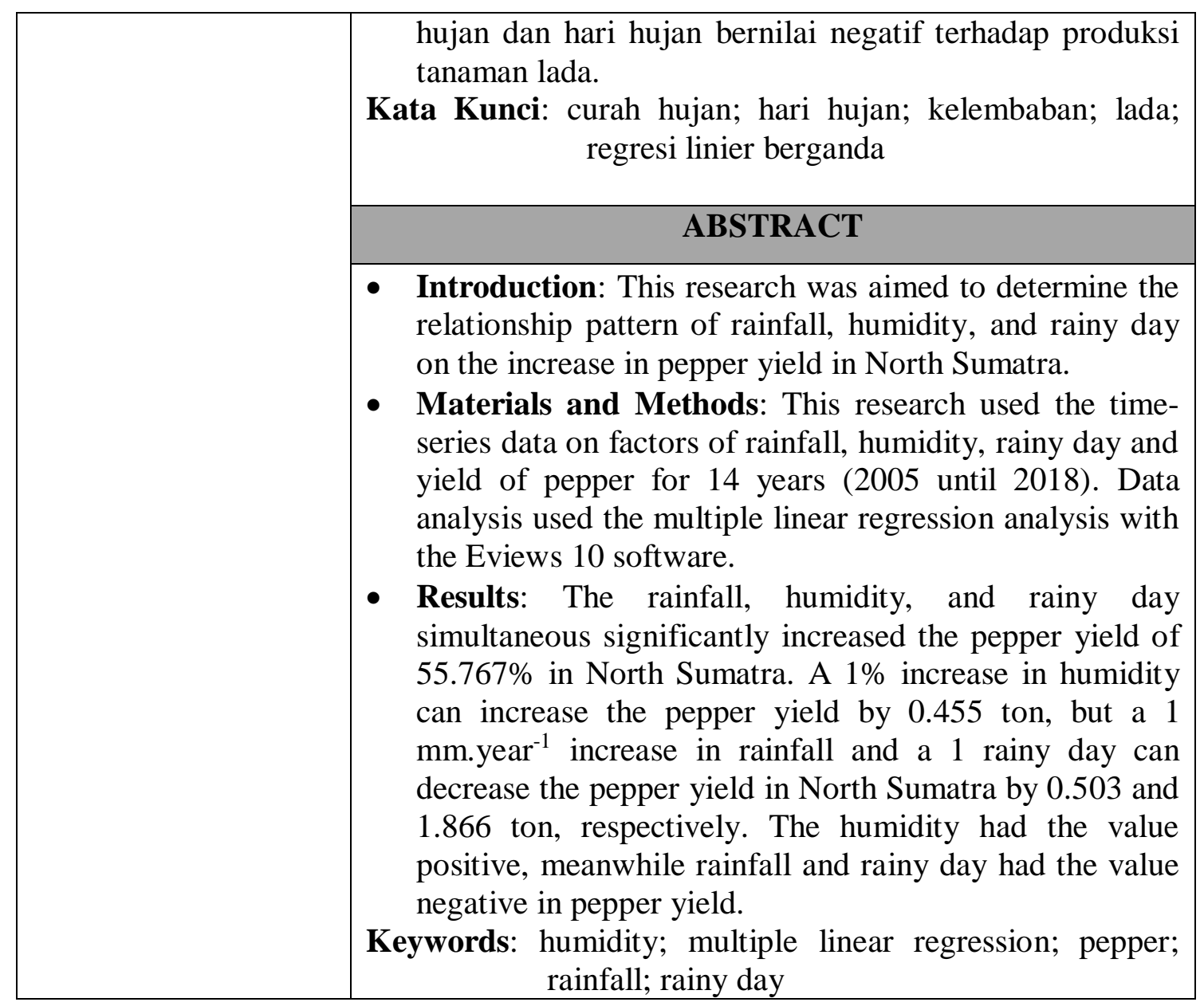

\section{PENDAHULUAN}

Tanaman lada (Piper nigrum L.) merupakan tanaman perkebunan dalam kelompok rempah-rempah yang bernilai ekonomis tinggi sebagai penghasil devisa negara untuk diekspor. Indonesia menempati urutan ke-empat sebagai produsn dan eksportir utama lada di dunia khususnya lada hitam dan lada putih (Asniah \& AS, 2012). Provinsi Sumatera Utara merupakan salah satu penghasil lada di Indonesia dengan produksi lada mencapai 87,04 ton dengan luas lahan 195,50 ha atau memiliki produktivitas 0,445 ton/ha pada Tahun 2018 dan dareah penyebarannya terluas secara berurutan terdapat di Kabupaten Pakpak Bharat, Dairi, Tapanuli Tengah, Mandailing Natal, Langkat, Simalungun, Toba, Samosir, dan Karo (BPS Sumatera Utara, 2019). Namun produktivitas lada dari Sumatera Utara berkontribusi sebesar 55,49\% terhadap produktivitas lada secara nasional (0,802 ton/ha) (Direktorat Jenderal Perkebunan, 2018). Tingginya kontribusi produktivitas lada dari Sumatera Utara sangat potensial untuk dikembangkan dalam mendukung ekspor lada.

Dengan demikian diperlukan pengkajian beberapa aspek yang mendukung produktivitas lada di Sumatera Utara, salah satunya yaitu aspek iklim. Secara umum, telah dilaporkan bahwa iklim berpengaruh terhadap peningkatan pertumbuhan dan produksi tanaman. Sumarlin et al., (2018) melaporkan bahwa faktor iklim signifikan 
mempengaruhi proses pertumbuhan dan produksi jagung di Kabupaten Konawe Selatan. Akumulasi satuan panas (heat unit) kisaran 1195,9-1290,9 ${ }^{\circ} \mathrm{C}$ d dapat mempengaruhi fenologi tanaman jagung pada fase pertumbuhan dari waktu tanam sampai panen. Tampubolon \& Sihombing, (2017) melaporkan bahwa produksi pertanian akan mengalami penurunan seiring dengan peningkatan curah hujan dan hari hujan masingmasing sebesar 5,90 dan 16,20 ton di Kota Medan. Santoso \& Layli, (2011) melaporkan bahwa tingginya curah hujan dapat menyebabkan akar tanaman jagung defisiensi oksigen dan perubahan iklim berdampak pada penurunan produksi dan pendapatan petani. Valliyodan et al., (2014) melaporkan bahwa banjir atau peningkatan curah hujan dapat menyebabkan kadar oksigen menjadi rendah di daerah perakaran sehingga menginduksi aerenkim lebih cepat dengan membentuk akar adventif tanaman kedelai. Oliosi et al., (2016) juga melaporkan bahwa kelembaban relatif merupakan faktor utama dalam produksi cabang tanaman kopi, jumlah cabang meningkat seiring dengan peningkatan kelembaban relatif.

Fenomena iklim ini harus juga mempengaruhi pertumbuhan dan produksi tanaman lada. Yudiyanto et al., (2014) melaporkan bahwa perubahan iklim signifikan mempengaruhi unsur makro dan mikro yang penting pada pertumbuhan dan produksi/ha tanaman lada hitam. Wirantika \& Hariyono, (2019) melaporkan bahwa curah hujan dan jumlah hari hujan yang tinggi dapat menghambat fase generatif (proses pembungaan) tanaman lada. Pengaruh iklim terhadap produksi lada di Sumatera Utara belum pernah dilaporkan. Dengan demikian diperlukan penelitian tentang pengaruh komponen iklim terhadap produksi lada di Sumatera Utara dengan harapan penelitian ini dapat menjadi pertimbangan dalam menentukan sebaran areal penanaman lada. Tujuan penelitian ini untuk mendapatkan pola hubungan curah hujan, hari hujan, dan kelembaban udara terhadap produksi tanaman lada di Sumatera Utara dan beberapa alternatif kebijakan yang dapat diterapkan.

\section{METODOLOGI PENELITIAN}

\section{Lokasi dan Data Penelitian}

Penelitian ini dilakukan di Provinsi Sumatera Utara. Penelitian ini menggunakan data time-series selama 14 tahun (2005-2018) meliputi data curah hujan (mm/tahun), hari hujan (hari), kelembaban udara (\%), dan produksi tanaman lada (ton). Semua data diambil dari Badan Pusat Statistik Provinsi Sumatera Utara. Semua parameter dependent dan independen menggunakan logaritma natural (ln) dikarenakan parameter yang digunakan memiliki satuan yang berbeda. Data logaritma natural dari produksi tanaman lada, curah hujan, kelembaban udara, dan hari hujan di Sumatera Utara dapat dilihat pada Tabel 1.

\section{Teknik Analisis Data dan Model Regresi}

Penelitian ini menggunakan metode deksriptif kuantitatif dengan tujuan untuk mendapatkan pengaruh curah hujan, kelembaban udara, dan hari hujan dalam mempengaruhi produksi lada di Sumatera Utara. Penelitian ini dianalisis regresi linier 
berganda menggunakan software EViews 10, sehingga diperoleh persamaan regresi linier berganda menurut Ünver \& Gamgam, (1999):

$$
\mathbf{Y}=\mathbf{a}+\mathbf{b}_{1} \mathbf{C H}+\mathbf{b}_{2} \mathbf{K U}+\mathbf{b}_{3} \mathbf{H H}
$$

$\begin{array}{ll}\mathrm{Y} & \text { : Produksi tanaman lada } \\ \mathrm{a} & \text { : Intersep dari sumbu } \mathrm{Y} \\ \mathrm{b} & \text { : Koefisien regresi linier berganda } \\ \mathrm{CH} & \text { : Curah Hujan } \\ \mathrm{KU} & \text { : Kelembaban Udara } \\ \mathrm{HH} & \text { : Hari Hujan }\end{array}$

Tabel 1. Logaritma natural (ln) data produksi tanaman lada, curah hujan, kelembaban udara, dan hari hujan selama 14 tahun (2005-2018) di Sumatera Utara.

\begin{tabular}{ccccc}
\hline Tahun & Produksi Lada & Curah Hujan & Kelembaban Udara & Hari Hujan \\
\hline 2005 & 4,514 & 7,651 & 4,317 & 5,328 \\
2006 & 4,444 & 7,960 & 4,443 & 5,242 \\
2007 & 4,461 & 7,913 & 4,407 & 5,226 \\
2008 & 4,573 & 7,702 & 4,431 & 5,273 \\
2009 & 4,423 & 7,689 & 4,454 & 5,338 \\
2010 & 4,484 & 7,381 & 4,419 & 5,153 \\
2011 & 4,500 & 7,867 & 4,431 & 5,293 \\
2012 & 4,493 & 7,679 & 4,407 & 5,182 \\
2013 & 4,595 & 7,072 & 4,419 & 5,318 \\
2014 & 5,088 & 7,621 & 4,489 & 5,170 \\
2015 & 5,130 & 7,436 & 4,407 & 5,106 \\
2016 & 4,771 & 7,777 & 4,382 & 5,308 \\
2017 & 4,434 & 7,671 & 4,407 & 5,347 \\
2018 & 4,466 & 7,796 & 4,344 & 5,278 \\
\hline
\end{tabular}

Sumber: Badan Pusat Statistik Sumatera Utara 2005-2019 dan data diolah

\section{Evaluasi Asumsi Klasik}

Data curah hujan, kelembaban udara, dan hari hujan dalam mempengaruhi produksi tanaman lada dapat dianalisis melalui pengujian statistik jika memenuhi syarat uji asumsi klasik. Ariefianto, (2012) menyatakan bahwa uji asumsi klasik meliputi uji normalitas, uji heteroskedastisitas, uji multikolinearitas, dan uji autokorelasi.

Uji normalitas berfungsi untuk mengetahui variabel pengganggu atau residual berdistribusi normal atau tidak dengan melihat nilai probabiliti pada grafik Jarque-Bera. Model regresi tergolong baik jika data berdistribusi normal. Jika probabiliti > 0,05 diklasifikasikan berdistribusi normal, tetapi jika probabiliti $<0,05$ diklasifikasikan tidak berdistribusi normal.

Uji heteroskedastisitas dilakukan dengan metode Glejser dengan cara melihat nilai Prob Chi-square. Apabila nilai Prob Chi-square $<5 \%$ maka terjadi heteroskedastisitas, sedangkan Prob Chi-square > 5\% maka tidak terjadi heteroskedastisitas.

Uji multikolinearitas berfungsi untuk mengetahui ada atau tidaknya hubungan linear antar variabel independen dalam model regresi menggunakan matriks Pearson 
Correlation. Model regresi tergolong baik jika tidak terjadi multikolinieritas dengan melihat nilai matriks Pearson Correlation < 0,9 (Ghozali, 2001).

Uji autokorelasi berfungsi untuk mengetahui ada atau tidaknya penyimpangan yang terjadi antara residual pada satu pengamatan dengan pengamatan lain pada model regresi dengan melihat nilai Durbin Watson (DW) saat analisis data dan dibandingkan dengan tabel Durbin Watson. Tidak terjadinya autokorelasi menunjukkan model regresi yang baik. Trihendardi, (2007) melaporkan jika 1,65 < DW < 2,35 maka model regresi tidak terjadi autokorelasi; jika 1,21 < DW $<1,65$ atau 2,35 < DW $<2,79$ maka model regresi tidak dapat disimpulkan; dan jika nilai DW $<1,21$ atau DW $>2,79$ maka model regresi terjadi autokorelasi.

\section{Evaluasi Statistik}

Pengujian statistik pada penelitian ini meliputi uji $\mathrm{F}$, uji $\mathrm{t}$, dan koefisien determinasi. Uji F (keseluruhan) berfungsi untuk mengetahui apakah curah hujan, kelembaban udara, dan hari hujan memiliki pengaruh signifikan secara simultan terhadap produksi tanaman lada di Sumatera Utara dengan cara melihat nilai sig. Jika sig uji $\mathrm{F}<5 \%$, maka curah hujan, kelembaban udara, dan hari hujan signifikan secara simultan mempengaruhi produksi tanaman lada. Jika sig uji $\mathrm{F}>5 \%$ maka curah hujan, kelembaban udara, dan hari hujan berpengaruh tidak nyata secara simultan mempengaruhi produksi tanaman lada.

Uji t dilakukan untuk menguji koefisien dugaan dari curah hujan, kelembaban udara, dan hari hujan secara parsial berdampak signifikan atau tidak terhadap terhadap produksi tanaman lada di Sumatera Utara. Uji t dilakukan dengan membandingkan nilai probabiliti pada t-statistik dengan signifikan 5\%. Jika probabiliti $<5 \%$ maka curah hujan, kelembaban udara, dan hari hujan berpengaruh nyata secara parsial terhadap produksi tanaman lada, sedangkan probabiliti > 5\% maka curah hujan, kelembaban udara, dan hari hujan berpengaruh tidak nyata secara parsial terhadap produksi tanaman lada. Koefisien determinasi (R) digunakan untuk mengetahui seberapa besar perubahan atau variasi suatu variabel yang dijelaskan oleh perubahan atau variasi pada variabel lainnya. Nilai $\mathrm{R}$ yang digunakan berkisar $0<\mathrm{R}<1$. Jika angka koefisien determinasi mendekati 1 (satu), maka model tersebut dianggap baik (Gujarati, 2007).

\section{HASIL DAN PEMBAHASAN}

\section{Evaluasi Asumsi Klasik}

Uji normalitas dari faktor curah hujan, kelembaban udara, dan hari hujan terhadap produksi tanaman lada selama 14 tahun (2005-2018) di Sumatera Utara (Gambar 1). Nilai probabiliti pada grafik Jarque-Bera sebesar 0,6307 dan lebih besar dibandingkan probabiliti 5\%. Hal ini berarti data curah hujan, kelembaban udara, hari hujan dan produksi tanaman lada yang digunakan pada penelitian ini berdistribusi normal, artinya data yang digunakan sudah memenuhi syarat untuk dilanjutkan ke pengujian statistik.

Uji heteroskedastisitas dari faktor curah hujan, kelembaban udara, dan hari hujan terhadap produksi tanaman lada selama 14 tahun (2005-2018) di Sumatera Utara dapat 
dilihat pada Tabel 2. Nilai Prob Chi-square sebesar 0,1661 dan lebih besar dibandingkan probabiliti 5\%. Hal ini menunjukkan bahwa data curah hujan, kelembaban udara, hari hujan dan produksi tanaman lada yang digunakan pada penelitian ini tidak terjadi heteroskedastisitas.
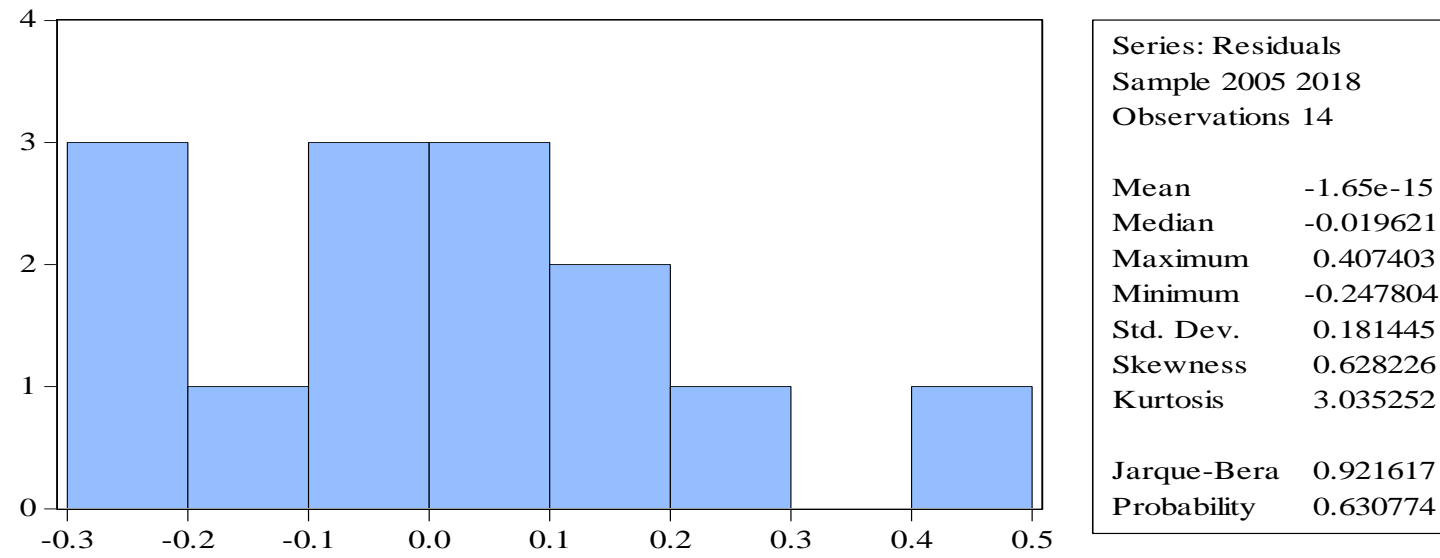

Gambar 1. Uji normalitas faktor curah hujan, kelembaban udara, dan hari hujan terhadap produksi tanaman lada selama 14 tahun di Sumatera Utara.

Tabel 2. Heteroskedastisitas dari faktor curah hujan, kelembaban udara, dan hari hujan terhadap produksi tanaman lada selama 14 tahun di Sumatera Utara

\begin{tabular}{lcll}
\hline Heteroskedasticity Test: Glejser & & \\
\hline F-statistic & 1.898131 & Prob. F (3,10) & 0.1939 \\
Obs*R-squared & 5.079616 & Prob. Chi-Square (3) & 0.1661 \\
\hline
\end{tabular}

Hasil pengujian multikolinearitas dari faktor curah hujan, kelembaban udara, dan hari hujan terhadap produksi tanaman lada selama 14 tahun (2005-2018) di Sumatera Utara dapat dilihat pada Tabel 3.

Tabel 3. Matriks pearson correlation pada uji multikolinearitas dari faktor curah hujan, kelembaban udara, dan hari hujan terhadap produksi tanaman lada selama 14 tahun di Sumatera Utara

\begin{tabular}{lccc}
\hline \multicolumn{1}{c}{ Variabel } & Curah Hujan & Kelembaban Udara & Hari Hujan \\
\hline Curah Hujan & 1 & & \\
Kelembaban Udara & 0.046 & 1 & 1 \\
Hari Hujan & 0.156 & 0.280 & 1 \\
\hline
\end{tabular}

Tabel 3 menjelaskan bahwa faktor curah hujan, kelembaban udara, dan hari hujan terhadap produksi tanaman lada memiliki nilai matriks pearson correlation lebih rendah dari 0,9. Hal ini menunjukkan bahwa faktor-faktor tersebut tidak terjadi multikolinieritas.

Hasil pengujian autokorelasi dari faktor curah hujan, kelembaban udara, dan hari hujan terhadap produksi tanaman lada selama 14 tahun (2005-2018) di Sumatera Utara dapat dilihat pada Tabel 4. Hasil analisis menunjukkan bahwa nilai Durbin Watson sebesar 2,31487. Hal ini menunjukkan bahwa faktor curah hujan, kelembaban udara, dan hari hujan terhadap produksi tanaman lada berada pada kisaran 1,65 $<$ DW $<2,35$ atau tidak terjadi autokorelasi. 


\section{Model Regresi Linier Berganda}

Model analisis regresi linier berganda faktor curah hujan, kelembaban udara, dan hari hujan terhadap produksi tanaman lada selama 14 tahun (2005-2018) di Sumatera Utara dapat dilihat pada Tabel 4.

Tabel 4. Model analisis regresi linier berganda faktor curah hujan, kelembaban udara, dan hari hujan terhadap produksi tanaman lada di Sumatera Utara.

Dependent Variable: Y

Method: Least Squares

Date: 10/03/20 Time: 01:13

Sample: 20052018

Included observations: 14

\begin{tabular}{lclcc}
\hline \multicolumn{1}{c}{ Variable } & Coefficient & Std. Error & t-Statistic & Prob. \\
\hline Konstanta & 13.53704 & 8.374451 & 1.616469 & 0.1371 \\
Curah Hujan & -0.503365 & 0.249017 & -2.021410 & 0.0708 \\
Kelembaban Udara & 0.454861 & 1.387653 & 0.327792 & 0.7498 \\
Hari Hujan & -1.865842 & 0.790914 & -2.359097 & 0.0400 \\
\hline R-squared & 0.557672 & Mean dependent var & 1.884714 \\
Adjusted R-squared & 0.424974 & S.D. dependent var & 0.272818 \\
S.E. of regression & 0.206879 & Akaike info criterion & -0.078406 \\
Sum squared resid & 0.427990 & Schwarz criterion & 0.104181 \\
Log likelihood & 4.548844 & Hannan-Quinn criter. & -0.095308 \\
F-statistic & 4.202560 & Durbin-Watson stat & 2.314875 \\
Prob (F-statistic) & 0.036380 & & \\
\hline
\end{tabular}

Tabel 4 diperoleh persamaan regresi linier berganda faktor curah hujan, kelembaban udara, dan hari hujan terhadap produksi tanaman lada sebagai berikut:

$$
\hat{\mathbf{Y}}=\mathbf{1 3 , 5 3 7 0 4}-\mathbf{0 , 5 0 3 3 6 5} \mathrm{CH}+\mathbf{0 , 4 5 4 8 6 1} \mathrm{KU}-\mathbf{1 , 8 6 5 8 4 2} \mathrm{HH}
$$

Persamaan diatas menjelaskan bahwa setiap peningkatan $1 \%$ kelembaban udara (KU) maka dapat meningkatkan produksi tanaman lada sebesar 0,455 ton, namun setiap peningkatan $1 \mathrm{~mm} /$ tahun curah hujan $(\mathrm{CH})$, dan 1 hari hujan $(\mathrm{HH})$ dapat menurunkan produksi tanaman lada di Sumatera Utara masing-masing sebesar 0,503 dan 1,866 ton.

\section{Evaluasi Statistik}

Berdasarkan Tabel 4, diperoleh nilai F-statistik sebesar 1,898 dengan probabiliti 0,036380 atau lebih kecil dari probabiliti 5\%. Hal ini menunjukkan bahwa curah hujan, kelembaban udara, dan hari hujan secara keseluruhan signifikan mempengaruhi produksi tanaman lada di Sumatera Utara selama 14 tahun (2005-2018). Tabel 4 menunjukkan bahwa nilai koefisien determinasi (R-squared) sebesar 0,557672 artinya curah hujan, kelembaban udara, dan hari hujan memiliki pengaruh sebesar 55,767\% terhadap produksi tanaman lada di Sumatera Utara dan sisanya 44,233\% dipengaruhi oleh faktor lainnya seperti teknik budidaya yang tepat, pemupukan yang berimbang dan status kesuburan tanah, pengendalian hama dan penyakit, dan operasional lainnya.

Hubungan curah hujan, kelembaban udara, dan hari hujan terhadap produksi tanaman lada di Sumatera Utara selama 14 tahun dapat dilihat pada Gambar 2. 

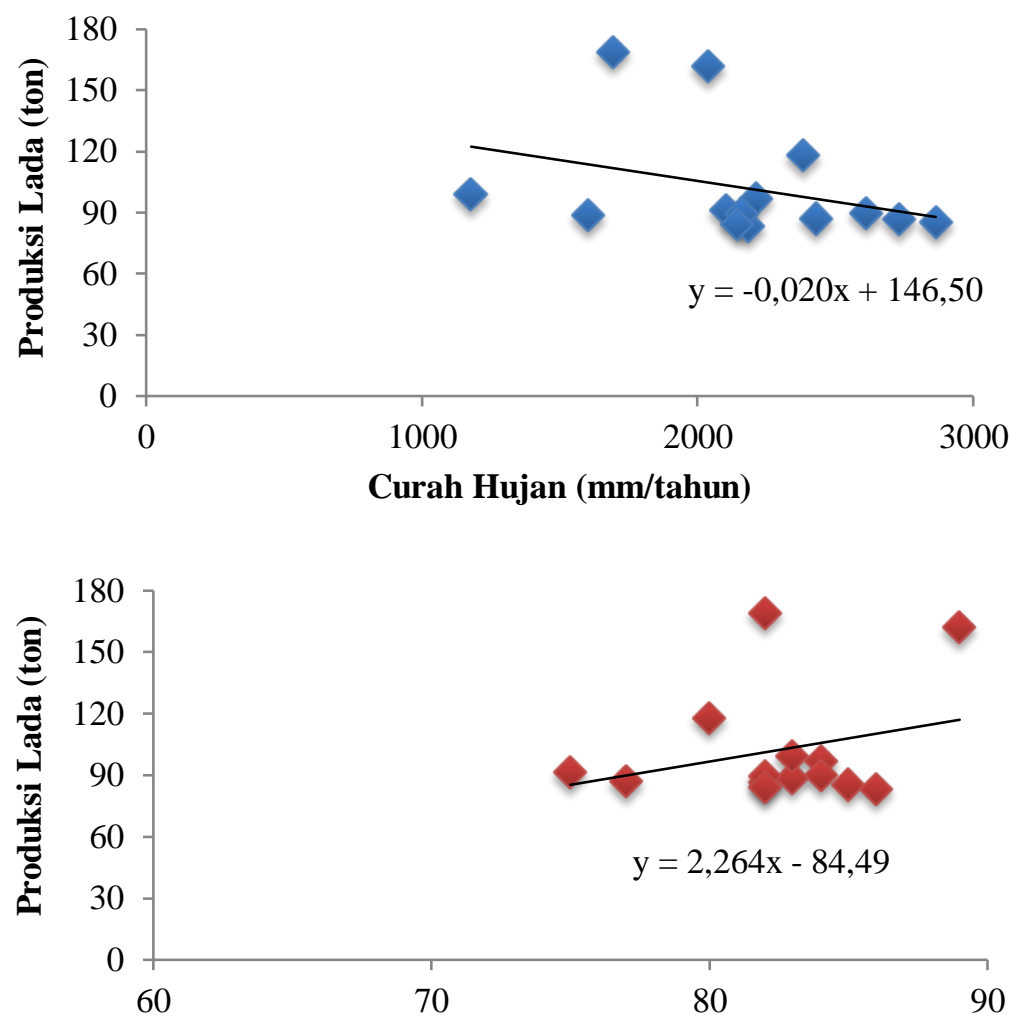

Kelembaban Udara (\%)

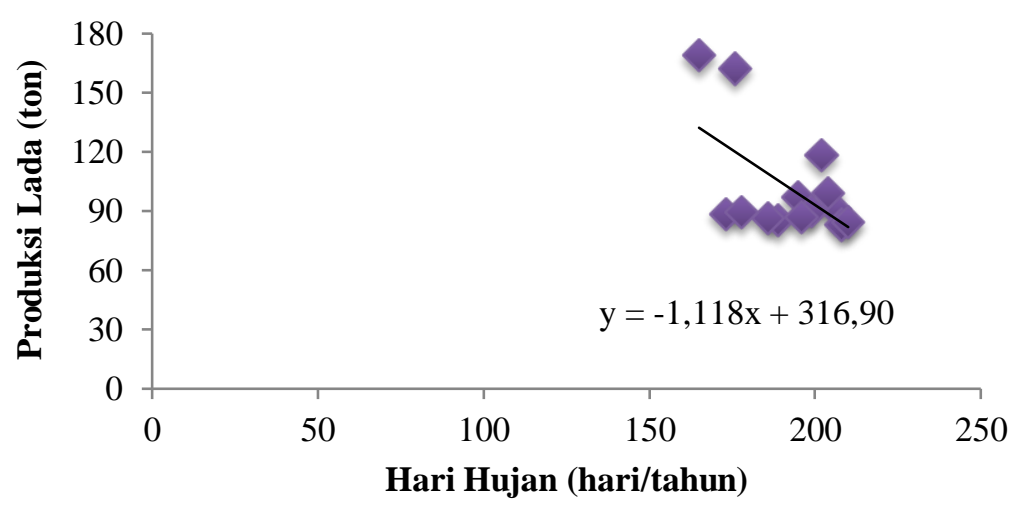

Gambar 2. Hubungan curah hujan, kelembaban udara, dan hari hujan terhadap produksi tanaman lada di Sumatera Utara.

Tabel 4 juga menunjukkan bahwa nilai probabiliti pada uji $\mathrm{t}$ dari faktor nilai hari hujan $(0,0400<5 \%)$ dengan nilai t-statistik sebesar $-2,359097$. Hal ini berarti faktor hari hujan secara parsial signifikan dan berpengaruh negatif terhadap produksi tanaman lada. Faktor curah hujan memiliki nilai probabiliti 0,0708 > 5\% dengan nilai t-statistik sebesar -2,021410. Hal ini berarti faktor hari hujan secara parsial tidak signifikan dan berpengaruh negatif terhadap produksi tanaman lada. Faktor kelembaban udara memiliki probabiliti 0,7498 > 5\% dengan nilai t-statistik sebesar 0,327792. Hal ini berarti faktor kelembaban udara secara parsial tidak signifikan, namun berpengaruh positif terhadap produksi tanaman lada di Sumatera Utara. 


\section{Pembahasan}

Pengaruh faktor curah hujan, kelembaban udara, dan hari hujan selama 14 tahun (2005-2018) secara keseluruhan signifikan meningkatkan produksi tanaman lada di Sumatera Utara sebesar 55,767\%. Menurut Yudiyanto et al., (2014) bahwa curah hujan, intensitas cahaya, dan kelembaban mikro signifikan meningkatkan produktivitas lada varietas natar-1 dan natar 2 di Provinsi Lampung. Sivaraman et al., (1999) menyatakan bahwa curah hujan 1250-2000 mm/tahun, suhu tropis, dan kelembaban udara relatif tinggi (60-95\%) dengan sedikit variasi panjang hari sepanjang tahun merupakan syarat ideal untuk tanaman lada. Kandiannan et al., (2011) menyatakan bahwa faktor iklim seperti suhu maksimum, suhu minimum, curah hujan, kelembaban relatif maksimum memiliki hubungan yang signifikan terhadap produksi lada. Srinivasan, (2007) melaporkan bahwa produksi lada hitam yang tinggi berhubungan dengan kelembaban relatif maksimum, diikuti curah hujan, suhu minimum, suhu maksimum, lama penyinaran, kecepatan angin, kelembaban relatif minimum, dan penguapan. Curah hujan merupakan faktor utama yang mempengaruhi pembungaan dan pembentukan buah yang mengarah pada peningkatan produksi tanaman lada hitam. Pradeepkumar et al., (1999) juga melaporkan bahwa rataan suhu maksimum dan kelembaban relatif minimum memiliki pengaruh 92,60\% dalam memprediksi produksi lada di India.

Persamaan regresi membuktikan bahwa kelembaban udara dapat meningkatkan produksi tanaman lada, namun curah hujan dan hari hujan menurunkan produksi lada. Setiap peningkatan $1 \%$ kelembaban udara dapat meningkatkan produksi tanaman lada sebesar 0,455 ton, namun peningkatan $1 \mathrm{~mm} /$ tahun curah hujan dan 1 hari hujan dapat menurunkan produksi lada masing-masing sebesar 0,503 dan 1,866 ton. Hal ini didukung dengan uji t-statistik kelembaban udara bernilai positif sedangkan curah hujan dan hari hujan bernilai negatif (Tabel 4). Selain itu, pola sebaran kelembaban udara menunjukkan linier positif sedangkan curah hujan dan hari hujan menunjukkan linier negatif terhadap produksi tanaman lada di Sumatera Utara selama 2005-2018 (Gambar 2). Produksi lada tertinggi terdapat pada kelembaban udara 82\%; curah hujan 1696 mm/tahun, dan 165 hari hujan/tahun atau 13,75 hari hujan/bulan. Menurut Krishnamurthy, (2011) curah hujan berpengaruh positif meningkatkan produktivitas lada, namun curah hujan juga berpengaruh tidak signifikan pada beberapa daerah. Wirantika \& Hariyono, (2019) menyatakan bahwa curah hujan, hari hujan, dan bulan basah memiliki pengaruh positif masing-masing 0,82; 0,68 dan 0,64 terhadap produktivitas lada di Kecamatan Sekampung Udik, Kabupaten Lampung Timur. Setiap peningkatan curah hujan, hari hujan, dan bulan basah maka akan meningkatkan produktivitas lada. Sushna, (2016) menyatakan bahwa curah hujan dan kelembaban relatif mendukung pertumbuhan daun baru, buku tanaman, percabangan dan akar adventif tanaman lada hitam. Curah hujan yang optimum untuk mendukung pertumbuhan lada berkisar $100-150 \mathrm{~mm} /$ bulan, suhu maksimum $30-32^{\circ} \mathrm{C}$, suhu minimum $23-25^{\circ} \mathrm{C}$, kelembaban relatif pada pagi hari berkisar $80-90 \%$ dan pada siang hari berkisar $60-70 \%$. 


\section{ALTERNATIF KEBIJAKAN}

Berdasarkan temuan riset ini, maka beberapa alternatif kebijakan yang dapat digunakan bagi pemerintah daerah dengan masyarakat dalam mengoptimalkan produksi tanaman lada dari aspek iklim di Sumatera Utara, antara lain:

1. Menyesuaikan pola dan waktu tanam dengan membuat kalender tanaman lada berdasarkan pola curah hujan dan hari hujan bertujuan menghindari hujan yang berlebihan.

2. Memperluas areal dan menggalakkan penanaman lada di kabupaten-kabupaten penghasil lada dan kabupaten lainnya yang berpotensi memenuhi syarat tumbuh tanaman lada di Sumatera Utara.

3. Memodifikasi areal penanaman dengan sistem tumpang sari dengan tujuan menjaga kelembaban udara yang dibutuhkan tanaman lada.

4. Membentuk bendungan, waduk, dan embung di areal penanaman lada yang tujuannya dapat menampung air hujan yang berlebihan dan dapat digunakan sebagai sumber air jika terjadi musim kemarau.

5. Perakitan varietas unggul tanaman lada tahan banjir dan kekeringan serta memiliki produksi tinggi dengan mengaktifkan kerjasama riset dengan pemerintah pusat agar adaptif pada kondisi curah hujan dan jumlah hari hujan yang berlebihan.

\section{KESIMPULAN}

Faktor curah hujan, kelembaban udara, dan hari hujan secara keseluruhan signifikan meningkatkan produksi tanaman lada sebesar $55,767 \%$ selama 14 tahun (2005-2018) di Sumatera Utara. Setiap peningkatan 1\% kelembaban udara dapat meningkatkan produksi tanaman lada sebesar 0,455 ton, namun peningkatan 1 $\mathrm{mm} /$ tahun curah hujan dan 1 hari hujan dapat menurunkan produksi lada masing-masing sebesar 0,503 dan 1,866 ton. Secara t-statistik, kelembaban udara bernilai positif sedangkan curah hujan dan hari hujan bernilai negatif terhadap produksi tanaman lada.

\section{DAFTAR PUSTAKA}

Ariefianto, M. D. (2012). Ekonometrika esensi dan aplikasi dengan menggunakan Eviews. Penerbit Erlangga, Jakarta.

Asniah, S., \& AS, T. W. (2012). Survei kejadian penyakit busuk pangkal batang (Phytophthora capsici) tanaman lada (Piper nigrum L.) di Kabupaten Konawe Selatan. Jurnal Agroteknos, 2(3), 151-157.

Badan Pusat Statistik Sumatera Utara. (2019). Provinsi Sumatera Utara dalam angka 2005-2019. Medan, Sumatera Utara, Indonesia.

Direktorat Jenderal Perkebunan (2018). Statistik Perkebunan Indonesia 2017-2019, Lada. Kementerian Pertanian, Jakarta. 48p.

Ghozali, I. (2001). Ekonometrika: teori dan aplikasi dengan SPSS. Edisi Pertama. Universitas Diponegoro, Semarang.

Gujarati, D. N. (2007). Dasar-dasar ekonometrika. Penerbit Erlangga, Jakarta.

Kandiannan, K., Parthasarathy, U., Krishnamurthy, K. S., Thankamani, C. K., Srinivasan, V., \& Aipe, K. C. (2011). Modeling the association of weather and black pepper yield. Indian Journal of Horticulture, 68(1), 96-102. 
Krishnamurthy, K. S., Kandiannan, K., Sibin, C., Chempakam, B., \& Ankegowda, S. J. (2011). Trends in climate and productivity and relationship between climatic variables and productivity in black pepper (Piper nigrum). Indian Journal of Agricultural Sciences, 81(8), 729-733.

Oliosi, G., Giles, J. A. D., Rodrigues, W. P., Ramalho, J. C., \& Partelli, F. L. (2016). Microclimate and development of'Coffea canephora'cv. Conilon under different shading levels promoted by Australian cedar (Toona ciliata M. Roem. var. Australis). Australian Journal of Crop Science, 14(4), 528-538. http://doi.org/10.21475/ajcs.2016.10.04.p7295x.

Pradeepkumar, T., Kumaran, K., Aipe, K. C., \& Manomohandas, T. P. (1999). Influence of weather on the yield of pepper cv. panniyur 1 (Piper nigrum L.). Journal of Tropical Agriculture, 37(1\&2), 56-59. Diakses dari: https://agris.fao.org/agris-search/search.do?recordID=IN2002000453.

Santoso, H., \& Layli, N. (2011). Dampak perubahan iklim terhadap produksi dan pendapatan usahatani jagung (Zea mays L). AGRISE: Agricultural SocioEconomics Journal, 11(3), 151-163.

Sivaraman, K., Kandiannan, K., Peter, K. V., \& Thankamani, C. K. (1999). Agronomy of black pepper (Piper nigrum L.) - A review. Journal of Spices and Aromatic Crops, $\quad 8(1), \quad 01-18 . \quad$ Diakses dari: https://updatepublishing.com/journal/index.php/josac/article/view/4508.

Srinivasan, K. (2007). Black pepper and its pungent principle-piperine: a review of diverse physiological effects. Critical Reviews in Food Science and Nutrition, 47(8), 735-748. https://doi.org/10.1080/10408390601062054.

Sumarlin, S., Karimuna, L., \& Syaf, H. (2018). Pengaruh faktor iklim terhadap pertumbuhan dan produksi tanaman jagung (Zea mays L.). Berkala Penelitian Agronomi, 6(1), 17-24. http://dx.doi.org/10.33772/bpa.v6i1.7517.

Sushna, K. (2016). Influence of weather parameters on growth and yield of black pepper (Piper nigrum L.). Tesis. College of Horticulture, Vellanikkara. Diakses dari: https://krishikosh.egranth.ac.in/handle/1/5810025064.

Tampubolon, K., \& Sihombing, F. N. (2017). Pengaruh curah hujan dan hari hujan terhadap produksi pertanian serta hubungannya dengan PDRB atas harga berlaku di Kota Medan. Jurnal Pembangunan Perkotaan, 5(1), 35-41.

Trihendradi, C. (2007). Kupas Tuntas Analisis Regresi. Strategi Jitu melakukan Analisis Hubungan Causal. Penerbit Andi, Yogyakarta.

Ünver, Ö., \& Gamgam, H. (1999). Uygulamal istatistik yöntemler. Siyasal Kitabevi.

Valliyodan, B., Van Toai, T. T., Alves, J. D., De Fátima P. Goulart, P., Lee, J. D., Fritschi, F. B., Rahman, M. A., Islam, R., Shannon, J. G., \& Nguyen, H. T. (2014). Expression of root-related transcription factors associated with flooding tolerance of soybean (Glycine max). International Journal of Molecular Sciences, 15(10), 17622-17643. https://doi.org/10.3390/ijms151017622.

Wirantika, R., \& Hariyono, D. (2019). Studi perubahan curah hujan dan hubungannya dengan produktivitas tanaman lada (Piper nigrum L.) di Kabupaten Lampung Timur. Jurnal Produksi Tanaman, 7(4), 1271-1277.

Yudiyanto., Rizali, A., Munif, A., Setiadi, D., \& Qayim, I. (2014). Environmental factors affecting productivity of two indonesian varieties of black pepper (Piper nigrum L.). AGRIVITA, Journal of Agricultural Science, 36(3), 278-284. http://doi.org/10.17503/agrivita.v36i3.456. 